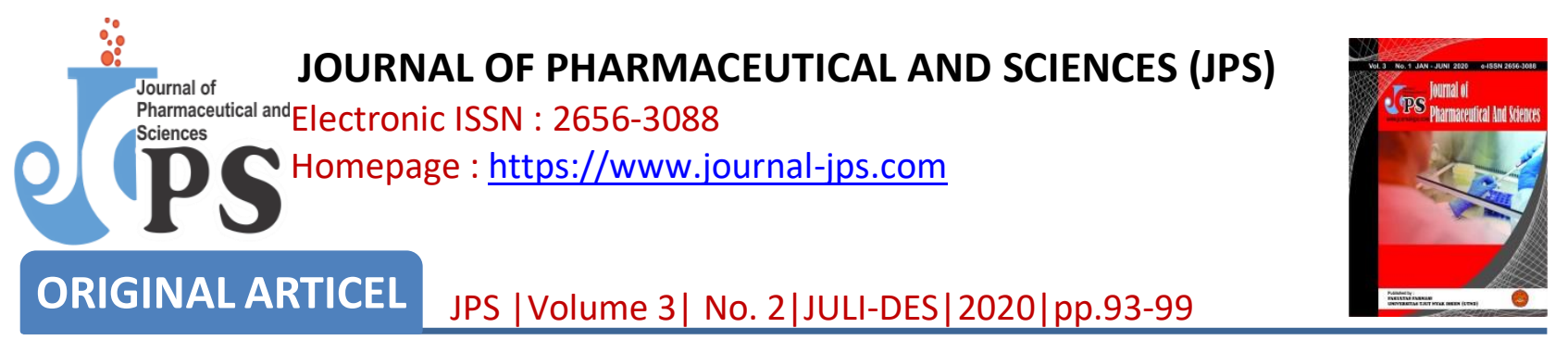

\title{
ANTIBACTERIAL ACTIVITY TEST OF ETHANOL EXTRACT FROM DRIED SIMPLICIA GARLIC (Allium sativum L.) TOWARD Bacillus cereus BACTERIA
}

\section{UJI AKTIVITAS ANTIBAKTERI EKSTRAK ETANOL DARI SIMPLISIA KERING BAWANG PUTIH (Allium sativum L.) TERHADAP BAKTERI Bacillus cereus}

\author{
Athaillah $^{1 *)}$ \& Ugi Diana Lestari ${ }^{1)}$ \\ ${ }^{1)}$ Prodi Farmasi Universitas Haji Sumatera Utara \\ Jl. Rumah Sakit Haji Medan, Kenangan Baru, Deli Serdang-Sumatera Utara-20371 \\ *e-mail auhor: atha237@gmail.com
}

\begin{abstract}
The research target to find out the extract activity dried simplisia of garlic (Allium sativum L.) as an antibacterial which is capable to inhibiting growth of Bacillus cereus bacterium, and then to check out the secondary of metabolites are flavonoid, alkaloid, saponin and tannin that contained in dried extract of garlic and to find out a concentration that has the most antibacterial activity which is capable to inhibiting growth of Bacillus cereus bacterium. Garlic was extracted with maceration method using a solvent ethanol $96 \%$. After the extract obtaned, phtochemical screening and standardization test subsequently. Thickening technique by evaporation used vacum rotary evaporator until thick extarct was obtained. Antibacterial activity thest by using disk diffusion method. This research was used variation of concentrations are $20,30.40,50,60,80$, $100 \%(b / v)$. The positive control used was ciprofloxacin and the negative control was sterile aquadest The result of phytochemical screening test, ethanol extract garlic (Allium sativum L.) positive contained compound alkaloid, flavonoid, saponin and tannin. Standardization of power simplisia fulfill the requirements set by Depkes RI 2000. The result of activity test of optimum antibacterial was obtained inhibitory power with the number $27 \mathrm{~mm}$ on $40 \%$ (b/v) concentration. This result is same as positive control. This proves that garlic (Allium sativum L.) have potential as antibacterial affects against Bacillus cereus bacterium.
\end{abstract}

Keywords : Dried simplisia, Garlic, Antibacterial, Bacillus cereus.

\footnotetext{
ABSTRAK

Penelitian bertujuan untuk mengetahui aktivitas ekstrak simplisia kering bawang putih (Allium sativum. L.) sebagai antibakteri yang dapat menghambat tumbuhnya bakteri Bacillus cereus, mengetahui senyawa metabolit sekunder yaitu senyawa flavonoid, alkaloid, saponin, dan tanin yang terdapat di dalam ekstrak kering bawang putih dan mengetahui konsentrasi yang mempunyai aktivitas antibakteri paling besar dalam menghambat pertumbuhan bakteri Bacillus cereus.
} 
Ekstrak Bawang putih (Allium sativum L.) diperoleh dengan metode maserasi dengan pelarut etanol $96 \%$. Hasil ekstrak yang diperoleh selanjutnya diuji skrining fitokimia dan standarisasi. Teknik pengentalan ekstrak etanol dilakukan dengan cara dievaporasi sampai diperoleh ekstrak kental menggunakan alat vacum rotary evaporator. Selanjutnya uji aktivitas antibakteri dengan metode difusi cakram. Dalam penelitian ini menggunakan variasi konsentrasi yaitu $20,30,40,50,60,80,100 \%$ (b/v). Kontrol positif yang digunakan adalah ciprofloxacin dan kontrol negatifnya adalah aquadest steril. Berdasarkan hasil uji skrining fitokimia terhadap hasil ekstrak diperoleh hasil positif mengandung senyawa metabolit sekunder. Untuk uji standarisasi serbuk simplisia diperoleh hasil memenuhi persyaratan yang ditetapkan oleh Depkes RI Tahun 2000. Hasil uji aktivitas antibakteri optimum didapatkan daya hambat sebesar $27 \mathrm{~mm}$ pada konsentrasi $40 \%$ (b/v). Hasil ini sama dengan daya hambat kontrol positif. Hasil ini menunjukkan bahwa bawang putih (Allium sativum L.) mempunyai potensi yang bagus sebagai antibakteri terhadap bakteri Bacillus cereus.

Kata kunci : Simplisia kering , Bawang putih, antibakteri, Bacillus cereus.

\section{PENDAHULUAN}

Sejak dahulu masyarakat telah mengenal bawang putih (Allium sativum L.) sebagai bumbu masak dan juga sebagai obat-obatan (Ross, O'Gara, Hill, Sleightholme, \& Maslin, 2001). Bawang putih (Allium sativum L.) sangat mudah diperoleh di seluruh Indonesia. Bawang putih (Allium sativum L.) juga digunakan sebagai obat tradisional oleh masyarakat (Syamsiah \& Tajudin, 2003).

Bawang putih (Allium sativum L.) mengandung senyawa-senyawa metabolit yaitu saponin, alkaloid dan juga tanin. Tanin bekerja dengan cara mengganggu permebilitas sel bakteri sehingga membran sel atau dinding sel jadi kerut. Alkaloid bekerja dengan mengganggu kompenen peptidoglikan dalam sel bakteri menyebabkan dinding sel tidak dapat terbentuk dengan sempurna. Kemudian saponin dengan cara merusak membran sitoplasma sehingga membran sel menjadi bocor (Lingga \& Rustama, 2006).

Kasus Keracunan makanan yang diduga karena menelan mikroorganisme hidup adalah salah, hal ini sebenarnya disebabkan oleh faktor toksin yang disekresikan oleh mikroorgnisme kedalam makanan. Beberapa Mikroorganisme penyebab keracunan makanan (foodborne bacteria) adalah Bacillus cereus, Campylobacter Salmonella, dan Escherichia coli (Kusumaningsih, 2010).

Bakteri Bacillus cereus merupakan sumber paling umum dijumpai sebagai penyebab utama pada gejala klinis yaitu muntah dan diare karena keracunan makanan dengan daging sebagai bahan dasarnya. Bakteri ini merupakan bakteri berbentuk batang dengan spora dan memiliki sifat sebagai gram positif, kemudian dari ukuran sel lebih besar jika dibanding dengan bakteri sejenis lainnya. Bakteri ini tumbuh secara aerob fakultatif. Spora yang dihasilkan oleh bakteri ini mampu bertahan dari panas dan dehidrasi (Amanati, 2014).

Kajian tentang bawang putih (Allium sativum L.) sebagai penghambat pertumbuhan bakteri didukung oleh penelitian (Prihandani, 2015) tentang uji daya hambat antibakteri larutan bawang putih (Allium sativum L.) terhadap Pseudomonas aeruginosa. Data optimum yang diperoleh yaitu pada konsentrasi $50 \%$ dengan diameter area hambat sebesar 19,90 mm. Data ini menjelaskan bahwa bawang putih (Allium sativum L.) tersebut dapat menghambat pertumbuhan dari bakteri Pseudomonas aeruginosa. Untuk mengetahui kemampuan daya hambat bawang putih (Allium sativum L.) terhadap bakteri lain, maka dilakukan penelitian terhadap bakteri Bacillus cereus.

\section{METODE PENELITIAN}

\section{Alat}

Peralatan yang digunakan di antaranya erlenmeyer (pyrex), cawan petri diameter $10 \mathrm{~cm}$, inkubator (binder), jarum ose, kaki tiga, kawat kasa, lemari pendingin (sharp), neraca analitik (acis), oven listrik (binder) dan autoklaf (HS-1212).

\section{Bahan}

Bahan yang digunakan adalah etanol $96 \%, \mathrm{HCl} 2 \mathrm{~N}$, amil alkohol, $\mathrm{HCl}$ pekat, aquadest, besi (III) klorida, bawang putih (Allium sativum L.), nutrient agar, nutrient borth, paper disk, pereaksi bouchardat, serbuk magnesium dan toluene, bakteri Bacillus cereus, pereaksi mayer, suspensi standar Mc Farland, pereaksi dragendroff, 


\section{Pembuatan Simplisia}

Bawang putih (Allium sativum L.) yang digunakan adalah bagian umbinya. Bahan ini diperoleh dari Pasar Raya MMTC Medan Sumatera Utara. Bawang putih di sortasi basah kemudian bawang putih dipisahkan dengan kulit dan dicuci menggunakan air mengalir, setelah itu bawang putih dirajang kecil-kecil, lalu dikeringkan dengan cara dianginkan.

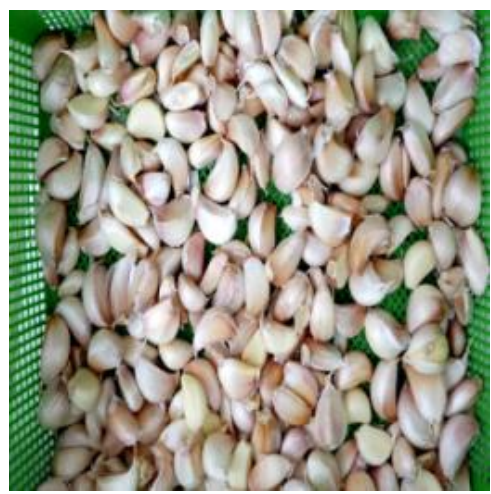

Gambar 1. Bawang putih (Allium sativum L.)

\section{Karakterisasi Simplisia}

Karakterisasi simplisia kering Bawang putih (Allium sativum L.) meliputi penetapan kadar sari larut dalam etanol, Uji kadar air, Penetapan kadar sari larut dalam air, Uji kadar abu dan Penetapan kadar abu yang tidak larut asam.

\section{Skrining Fitokimia}

Skrining fitokimia serbuk simplisia kering Bawang putih (Allium sativum L.) yaitu uji senyawa alkaloid, flavonoid, tanin dan saponin.

\section{Pembuatan Ekstrak Etanol dari Bawang putih (Allium sativum L.)}

Serbuk kering direndam dalam pelarut etanol $96 \%$ selama $7 \times 24$ jam. Kemudian dilakukan penyaringan untuk memisahkan 1 dari ampas. Selanjutnya dilakukan remaserasi dengan cara merendam ampas dari penyaringan tersebut dengan etanol $96 \%$ selama $7 \times 24$ jam. Disaring untuk memisahkan filtrat 2 dari ampas. Kemudian campurkan filtrat 1 dan filtrat 2. Hasilnya kemudian diuapkan menggunakan alat rotary vacum evaporator sampai menjadi kental.

\section{Sterilisasi Alat dan Bahan}

Dalam pemeriksaan mikrobiologi, alat dan bahan harus disterilkan terlebih dahulu sebelum digunakan. Untuk peralatan dilakukan dengan cara dipanaskan dalam oven dengan suhu $1700 \mathrm{C}$ dengan waktu 1 jam, sedangkan media dipanaskan dalam oven kira-kira 15 menit dengan suhu 1210C. Untuk jarum ose dan pinset dipanaskan dengan lampu Bunsen (Lay, 1994).

\section{Pembuatan medium nutrient agar}

Ditimbang $20 \mathrm{~g}$ nutrient agar, selanjutnya disuspensikan ke dalam aquadest $1 \mathrm{~L}$, kemudian dipanaskan sampai terlarut sempurna dan disterikan pada suhu $121^{\circ} \mathrm{C}$ sekitar 15 menit dalam autoklaf (Difco \& Manual, 2009).

\section{Pembuatan medium nutrient broth}

Serbuk nutrient broth ditimbang 8 gram, kemudian dilarutkan ke dalam aquadest steril secara perlahan sampai volumenya $1 \mathrm{~L}$ sambil dipanaskan agar semua bahan larut sempurna, selanjutnya disterilkan pada suhu $121^{\circ} \mathrm{C}$ sekitar 15 menit dalam autoklaf (Difco \& Manual, 2009).

\section{Uji Aktivitas Antibakteri}

Diukur sebanyak $0,1 \mathrm{ml}$ inokulum dan dimasukkan ke dalam cawan petri yang telah steril, kemudian ditambahkan $15 \mathrm{ml}$ pada suhu $50^{\circ} \mathrm{C}$ media nutrient agar. Cawan petri diletakkan di atas meja yang datar dan digoyang agar media dan suspensi bakteri dapat bercampur dengan baik. Kemudian dibiarkan sampai padat. Paper disk yang telah disiapkan dari hasil perendaman diletakkan pada tiap larutan uji dengan berbagai konsentrasi ditunggu hingga berdifusi sempurna, kemudian diletakkan pada media padat yang telah diinokulasi dengan bakteri dan selanjutnya dilakukan proses inkubasi selama 20 jam pada suhu $37^{\circ} \mathrm{C}$, setelah itu diambil paper disk dan diukur diameter daya hambat yang dihasilkan dengan jangka sorong. Pengujian ini dilakukan 3 kali pengulangan (Ditjen POM RI, 1995).

\section{HASIL DAN PEMBAHASAN}

\section{Hasil Standarisasi Serbuk Simplisia}

Berdasarkan data dari Tabel 1 menjelaskan hasil standarisasi serbuk simplisia bawang putih pada kadar air, kadar sari larut etanol, kadar sari larut air, kadar abu tidak larut asam dan kadar abu total memenuhi standar yang ditetapkan oleh Depkes RI Tahun 2000. Hasil penetapan standarisasi serbuk simplisia ditunjukkan pada Tabel 1. 
Tabel 1. Hasil standarisasi serbuk simplisia

\begin{tabular}{clcc}
\hline No & \multicolumn{1}{c}{ Parameter } & $\begin{array}{c}\text { Hasil } \\
(\mathbf{\%})\end{array}$ & $\begin{array}{c}\text { Parameter* } \\
\mathbf{( \% )}\end{array}$ \\
\hline 1. & Kadar Air & $7,89 \%$ & $<10 \%$ \\
2. & Kadar Sari Larut dalam Etanol & $75,6 \%$ & $>12,5 \%$ \\
3. & Kadar Sari Larut dalam Air & $26,26 \%$ & $>18 \%$ \\
4. & Kadar Abu tidak Larut dalam Asam & $1,44 \%$ & $<1,5 \%$ \\
5. & Kadar Abu Total & $5,25 \%$ & $<6 \%$ \\
\hline
\end{tabular}

*Sumber : Depkes RI, 2

\section{Hasil Skrining Fitokimia}

Berdasarkan data Tabel 1 diperoleh bahwa hasinyal positif terhadap senyawa metabolit sekunder yang diuji. Hal ini menunjukkan bahwa senyawa tersebut mampu menghambat pertumbuhan bakteri. Mekanisme peghambatan pertumbuhan bakteri dari senyawa alkaloid mampu mengganggu integritas komponen yang menyusun peptidoglikan dalam sel bakteri (Cushnie \& Lamb, 2005). Senyawa flavonoid dapat merusak permeabilitas pada dinding bakteri. Struktur flavonoid menyebabkan adanya perubahan mengakibatkan timbulnya efek toksik dalam bakteri
(Sabir, 2005). senyawa saponin memiliki mekanisme kerja yaitu dengan cara meningkatkan permeasi terhadap membran menyebabkan sel dari bakteri menjadi tidak stabil sehingga terjadinya hemolisis sel (Noer, Pratiwi, \& Gresinta, 2018). Senyawa tanin berperan sebagai antibakteri yaitu dengan cara memberikan efek toksik yang dihasilkan dari ikatan kompleks ion logam sehingga dapat menyebabkan kerusakan pada membran sel bakteri (Akiyama, Fujii, Yamasaki, Oono, \& Iwatsuki, 2001). Hasil skrining fitokimia serbuk simplisia kering (Allium sativum L.) ditunjukkan pada Tabel 2 :

Tabel 2. Hasil skrining fitokimia

\begin{tabular}{clcl}
\hline No. & Metabolit sekunder & Hasil & \multicolumn{1}{c}{ Keterangan } \\
\hline 1. & Flavonoid & + & Terbentuknya warna kuning \\
2. & Alkaloid & + & Terjadi endapan dan kekeruhan \\
3. & Saponin & + & Terbentuknya busa yang stabil \\
4. & Tanin & + & Terbentuknya warna hijau \\
\hline
\end{tabular}

\section{Keterangan:}
$(+)$ positif
: mengandung senyawa yang diuji
(-) negatif : tidak mengandung senyawa yang diuji

Hasil Pengujian Daya Hambat Terhadap Bakteri Bacillus cereus Pada Berbagai Konsentrasi Ekstrak Etanol Bawang Putih (Allium sativum L.)

Berdasarkan hasil pengukuran aktivitas antibakteri pada bawang putih memiliki daya hambat pada bakteri Bacillus cereus terlihat bahwa ekstrak etanol dari bawang putih dapat menghambat pertumbuhan bakteri Bacillus cereus. Hasil pengujian dapat dilihat pada Gambar 2. 


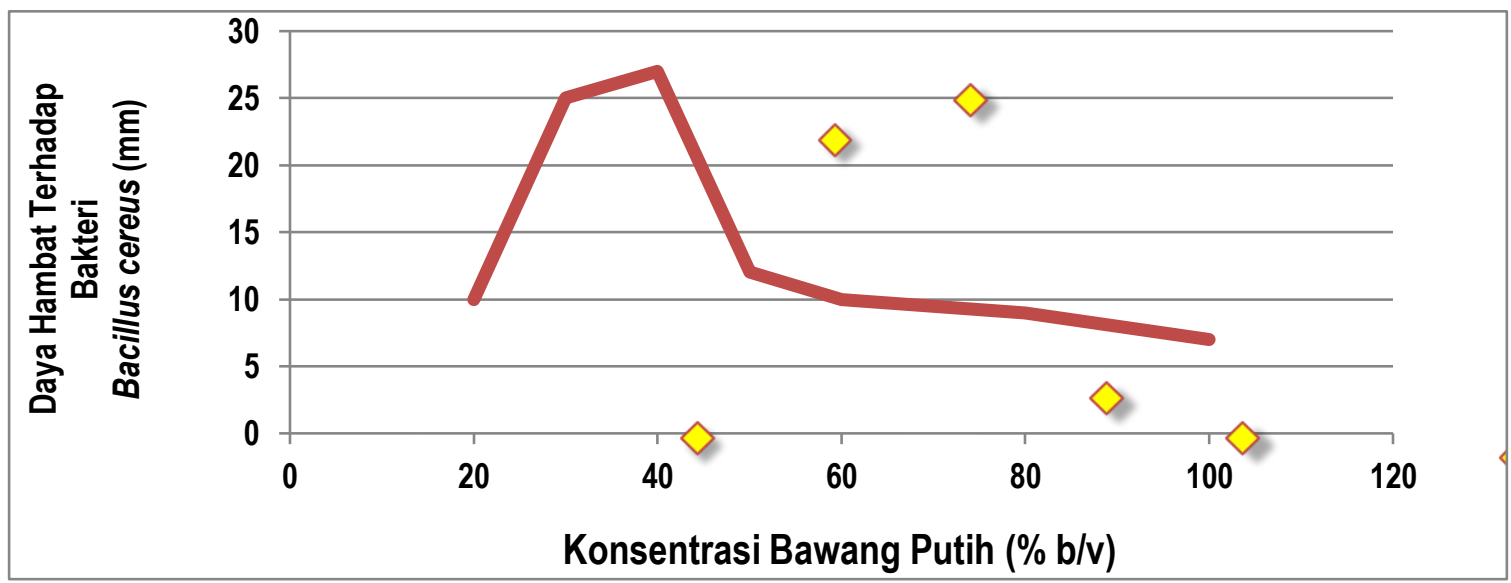

Gambar 2. Hasil Pengujian Daya Hambat Terhadap Bakteri Bacillus cereus Pada Berbagai Konsentrasi Ekstrak Etanol Bawang Putih (Allium sativum L.).

Berdasarkan Gambar 2, dapat dilihat bahwa konsentrasi yang optimum dan paling efektif dipilih berdasarkan daya hambat maksimum yang dihasilkan dari variasi konsentrasi yang diuji. Nilai ini diperoleh dengan cara mengukur diameter pada area bening yang dihasilkan karena area bening tersebut menunjukkan bahwa tidak adanya bakteri yang tumbuh. Variasi konsentrasi yang memiliki nilai daya hambat terbesar adalah pada konsentrasi $40 \%$ (bv) dengan rata-rata nilainya sebesar $27 \mathrm{~mm}$. Nilai ini merupakan yang paling tinggi dibandingkan dengan konsentrasi lainnya. Sedangkan nilai terendah terdapat pada konsentrasi $20 \%$ dan $100 \%$ (b/v). Hasil pengujian pada konsentrasi optimum dapat dilihat pada Gambar 3.

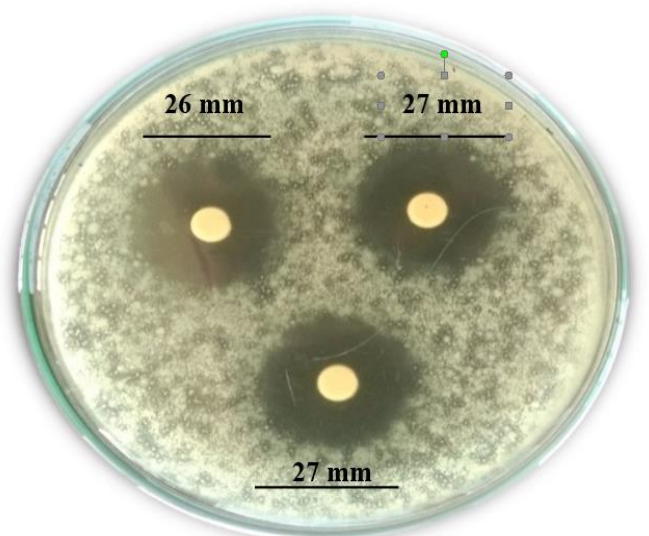

Gambar 3. Kemampuan daya hambat pada konsentrasi 40\% ekstrak bawang putih (Allium sativum L.) terhadap Bacillus cereus

Adanya perbedaan daya hambat bakteri terhadap variasi konsentrasi seperti ditunjukkan pada Gambar 2 ditentukan berdasarkan kemampuan dari bakteri ketika melawan senyawa antibakteri. Kemampuan dari bakteri melawan antibakteri tidak ditentukan oleh semakin tingginya konsentrasi akan tetapi berdasarkan kemampuan optimum yang ditunjukkan dengan data konsentrasi optimum. Hal ini sesuai dengan (Harborne, Sudiro, Padmawinata, \& Niksolihin, 1996) yang menyatakan bahwa pertumbuhan bakteri akan terganggu dengan baik pada kondisi perlakuan yang optimum, sehingga daya hambat optimum yang dihasilkan oleh zat antibakteri juga akan maksimal.

Hasil pengujian daya hambat terhadap kontrol positif yaitu antibiotik ciprofloxacin yaitu sebesar $27 \mathrm{~nm}$. Hasil ini sama dengan konsentrasi optimum $40 \%$ (b/v). Hal ini menjelaskan bahwa sampel yang diuji mempunyai potensi yang sangat bagus sebagai antibakteri terhadap bakteri Bacillus cereus. 
KESIMPULAN

Ekstrak simplisia kering dari bawang putih (Allium sativum. L) mampu menghambat pertumbuhan bakteri Bacillus cereus. Hasil rendemen ekstrak adalah sebesar 24,75\%. Ekstrak bawang putih yang mampu menghambat pertumbuhan bakteri Bacillus cereus pada konsentrasi 40\% dengan daya hambat sebesar 27 $\mathrm{mm}$ dan hasilnya sama dengan daya hambat pada kontrol positif.

\section{DAFTAR PUSTAKA}

Akiyama, H., Fujii, K., Yamasaki, O., Oono, T., \& Iwatsuki, K. (2001). Antibacterial action of several tannins against Staphylococcus aureus. Journal of Antimicrobial Chemotherapy, 48(4), 487-491. https://doi.org/10.1093/jac/48.4.487

Amanati, L. (2014). Uji Bakteri Staphylococcus Aureus Dan Bacillus Cereus Pada Produk Mi Instan Yang Beredar Di Pasaran ( Staphylococcus Aureus And Bacillus Cereus Bacteria Test On Instant Noodle Products At The Market ). Berita Litbang Industri, 3(2), 73-80.

Cushnie, T. P. T., \& Lamb, A. J. (2005). Antimicrobial activity of flavonoids. International Journal of Antimicrobial Agents, 26(5), 343-356. https://doi.org/ 10.1016/j.jjantimicag.2005.09.002

Departeman Kesehatan RI. 2000. Materia Medika. Jilid. VI. Diktorat Jendral POM-Depkes RI. Jakarta.

Departemen Kesehatan RI. 2000. Parameter Standar Umum Ekstrak Tumbuhan Obat. Diktor Jendral POM-Depkes RI. Jakarta.

Ditjen POM. (1995). Farmakope indonesia Edisi ke IV. Jakarta: Departemen Kesehatan Republik Indonesia. Hal. 1061, 1066.

Difco, \& Manual, B. (2009). Manual of Microbiological Culture Media (II; M. (ASCP) Mary Jo Zimbro, B.S., P. D. David A. Power, M. (ASCP) Sharon M. Miller, B.S., M. (ASCP) George E. Wilson, MBA, B.S., \& B. A. Julie A. Johnson, eds.). Retrieved from http://galachem.ru/upload/iblock/c79/difcobbl manual_2nded.pdf

Harborne, J. B., Sudiro, I., Padmawinata, K., \& Niksolihin, S. (1996). Metode fitokimia: penuntun cara modern menganalisis tumbuhan / J. B. Harborne; diterjemahkan oleh Kosasih Padmawinata dan Iwang Soediro; penyunting, Sofia Niksolihin. Retrieved from https://opac.perpusnas.go.id/ DetailOpac. aspx?id=577450\#

Kusumaningsih, A. (2010). Beberapa Bakteri Patogenik Penyebab Foodborne Disease pada Bahan Pangan Asal Ternak. Jurnal Wartazoa, 20(3), 103-111.

Lay, B. W. (1994). Analisis mikroba di laboratorium. PT. Raja Grafindo Persada. Jakarta, 168.

Lingga, M. E., \& Rustama, M. M. (2006). Uji aktivitas antibakteri dari ekstrak air dan etanol bawang putih (allium sativum I.) Terhadap bakteri gram negatif dan gram positif yang diisolasi dari udang dogol (Metapenaeus monoceros), udang lobster (Panulirus sp), dan udang rebon (Mysis dan Acetes). BIOTIKA Jurnal IImiah Biologi, 5(2).

Noer, S., Pratiwi, R. D., \& Gresinta, E. (2018). Penetapan Kadar Senyawa Fitokimia (Tanin, Saponin dan Flavonoid) sebagai Kuersetin Pada Ekstrak Daun Inggu (Ruta angustifolia L.). Jurnal Eksakta, 18(1), 1929. https://doi.org/10.20885/eksakta.vol18. iss 1.art3

Prihandani, S. S. (2015). Uji daya antibakteri bawang putih (Allium sativum L.) terhadap bakterl Staphylococcus aureus, Escherichia coli, Salmonella typhimurium dan Pseudomonas aeruginosa dalam meningkatkan keamanan pangan. Informatika Pertanian, 24(1), 53. https://doi.org/10.21082/ip.v24n1.2015.p5358

Ross, Z. M., O'Gara, E. A., Hill, D. J., Sleightholme, H. V., \& Maslin, D. J. (2001). Antimicrobial properties of garlic oil against human enteric bacteria: Evaluation of 
methodologies and comparisons with garlic oil sulfides and garlic powder. Applied and Environmental Microbiology, 67(1), 475480. https://doi.org/10.1128/AEM.67.1.475480.2001

Sabir, A. (2005). Aktivitas antibakteri flavonoid propolis Trigona $\mathrm{sp}$ terhadap bakteri Streptococcus mutans (in vitro) (In vitro antibacterial activity of flavonoids Trigona $\mathrm{sp}$ propolis against Streptococcus mutans). Dental Journal (Majalah Kedokteran Gigi), 38(3), $\quad$ 135. https://doi.org/10.20473/ j.djmkg.v38.i3.p135-141

Syamsiah, I. S., \& Tajudin. (2003). Khasiat \& manfaat bawang putih: raja antibiotik alami. Retrieved from https://agromedia.net/ katalog/khasiat-dan-manfaat-bawang-putihraja-antibiotik-alami/ 